\title{
Melanoma of the Ciliary Body and Choroid pT4a TNM Finding v7
}

National Cancer Institute

\section{Source}

National Cancer Institute. Melanoma of the Ciliary Body and Choroid pT 4a TNM Finding v7. NCl Thesaurus. Code C88702.

Tumor size category 4 without ciliary body involvement and extraocular extension. (from AJCC 7th Ed.) 